\title{
The issues of Internet Addiction and its implications on psychosocial aspects of Adolescents
}

\author{
Gnanaraj.S, Anand Jerard Sebastine.A, Parameswaran.S
}

\begin{abstract}
The research study examines the issues of internet addiction and its Implications on Psychosocial aspects of Adolescents. This was carried out based on the level of Internet addiction, Media \& Technology Usage and Attitude of Student's studying at Periyar Maniammai Institute of Science \& Technology (Deemed to be University),Vallam, Thanjavur, Tamilnadu, India. It was described in year 1996 by the psychologist Kimberly Young that Internet Addition (IA) a new form of disorder prevailing among various category of the people. The universe of the study comprises of 20 departments students studying in Periyar Maniammai Institute of Science \& Technology having strength of 1442 first and second year students, whereas 144 were taken as the final respondents. The researcher has adopted descriptive research design and used simple random sampling technique in this study. The study was administrated by the tools to measure the internet addition scale developed by Young in 1996. The Demographic factors such as age, gender and grade level were also examined and data analysis includes descriptive statistic and inferential statistic. The result of the study is minatory that the degrees of excessive internet users in the midst of the adolescents are frequent users. The adolescents spend too much of time, too much of money for internet usage, they also unnecessarily access the internet without having any purpose. It reveals that very little time were spent with a purpose, it also reduces the sleeping hours, leads to absence of interpersonal communication, creates social problem, lack of direct contacts, family related problems, psychological disorders, loneliness, losing their academic performance and facing physical problems. Therefore the study reveals that internet addiction leads the adolescents in a negative phase.
\end{abstract}

Index Terms: Internet Addiction, Media \& Technology Usage, Psychological disorder and Physical Problem.

\section{INTRODUCTION}

In the fast phased world Internet has become a highly essential and a basic amenity that influence every spear of life and among all age groups. Nowadays homes, educational institutions, libraries, railway stations, bus stands, cinema halls and internet cafes are more accessible to internet. We can widely witness adolescents using internet for common online activities like reading and writing emails, completing online games, carrying out school work and chatting on real time basis. The internet society report 2018 divulges that 3 billion peoples around the world were internet users. In diverse areas of science, business, education, culture and

Revised Manuscript Received on July 05, 2019.

S.Gnanaraj, Department of Social Work, Periyar Maniammai Institute of Science and Technology, Thanjavur, India.

Dr.A.Anand Jerard Sebastine, Department of Social Work, Periyar Maniammai Institute of Science \& Technology, Thanjavur, India.

S. Parameswaran, Department of Social Work, Periyar Maniammai Institute of Science \& Technology, Thanjavur, India. politics the emergence of internet claims to be a very useful tool. But the excessive and misuse of this tool has lead to internet addiction. The description of Internet Addiction by Shaw \& Black is "excessive or poorly controlled preoccupations, urges or behaviours regarding computer use and internet access that lead to impairment or distress".

A meta-analysis study (2014) among seven world regions covering 31 nations with 89,281 participants reported that there is $6 \%$ global prevalence of internet addiction. The negative implication of the Internet addiction affects both personal life and professional progress. The lack in sleep, nutrition, physical activities, social functions and also family relations gets affected personally. The advancement in the technology, easy internet accessibility, efficiency enhancement in the functionalities and affordable cost of the mobile phones leads to dependency on Internet.

\section{Internet Addiction}

Internet addiction is defined as "any online-related, compulsive behavior which interferes with normal living and causes severe stress on family, loved ones, friends and one's work environment". Internet addiction otherwise identified as Internet dependency or Internet compulsivity. Internet addiction also expressed as "compulsive behavior that completely controls the addict's life". Internet addicts give more importance to Internet than family and friends.

\section{LITERATURE REVIEW}

Yu \& Shek (2013) reviewing similar literatures in his conceptual study shows that online addiction influences life routines, parental relationship and health in relation to their incidences negatively.

\section{A. Psychological problem}

Young (1998) study evaluated its correlation with over usage of Internet, it examined the respondents whether they are experiencing irritability, restlessness, low mood, and anxiety when they are staying for a too much time on the Internet. The feeling of respondents whether having happy and satisfaction mood while web is also used as an exploration of this study. The attempt to avoid worry and problems by using online is also one of the psychological issues assessed in this study (Rotter, 1966; Ferraro et al., 2007). 


\section{B. Physical problems}

The Passion for surfing the internet has been used to find the duration of the sleeping time. It can also be assessed by the fatigue faces of the Internet users that will also determine the younger working adults' impact on Internet addiction. The excessive internet usage confirms the correlation with the migraine or headache problems also. (Shuhail \& Bergees, 2006; Jean et al., 2010). The previous studies reveals that excessive use of Internet invite quite a few physical problems like backache and body aches after they spent a long time in the Internet (Young, 2004).

\section{Behavioural problem}

Kubey et al. (2001) study examined the behaviour problems of the respondents and how they behave differently comparing to usual. It also analysed the respondents always intend to reschedule their time due to heavy Internet usage. Other researchers also administered research tools in the behavioral perspective and on the time spent on the Internet usage (Brenner, 1997; Scherer, 1997).

\section{Pornography and Risky Behaviour}

Sook and Chae (2012) Active use of pornography sites by $42 \%$ children falls between 10 to 17 years. It has been alarming that average children's age of first exposure is by 6 years (Wolack et al., 2007). It also revealed the Children's online participation associates with increased exposure to online risks. Also has a moderate association with the Internet skills of the children and parental restrictive mediation.

\section{RESEARCH MTHODOLOGY}

\section{A. Objectives}

1. To study the socio demographic profile of the Internet addicts

2. To identify the level of the respondents internet addiction

3. To bring out Internet Addiction and its implications on psychosocial aspects of the respondents

\section{B. Research Design}

The study design is descriptive and attempts to find out the students socio demographic profile, level of internet addiction and its implications on psychosocial aspects of adolescents studying at Periyar Maniammai Institute of Science \& Technology, Vallam, Thanjavur, Tamilnadu, India.

\section{Universe and Sampling}

The universe of the present study consists of students of 20 departments in Periyar Maniammai Institute of Science \&Technology which constitute selected 144 respondents from the 1442 adolescents studying first and second year. Researcher applied simple random sampling technique for this study.

\section{Tools for Data Collection:}

1. A self-prepared Interview Schedule

2. Internet Addiction Test (IAT) which is developed by kimbery Young 1996 and demographic factors like age, gender and grade of level that administrated to measure the IA. Internet Addiction Scale has 20 items related with internet use, its containing compulsive use, psychological dependence, and withdrawal, as well as related problems of sleep, school, time management and family. For each item, a classified response can be selected $(1=$ "not at all" to $5=$ "always"). The least score being 20 whereas the extreme is 100, when upper the score, the greater will be the level of IA. Based on Young suggestion, cut-off scores for the Internet Addiction Test were used to categorize Internet handlers based on the severity of their addictive behaviour.

\section{DATA ANALYSIS}

The data were collected using the above mentioned appropriate tools from the selected respondents. The Quantitative data were analysed using SPSS.

TABLE 1 - Socio Demographic Profile

\begin{tabular}{|c|l|l|r|r|}
\hline S.No & \multicolumn{1}{|c|}{ Variables } & Particulars & Frequency & \multicolumn{1}{|c|}{ Percent } \\
\hline 1. & Age & $17-19$ & 144 & 100 \\
\hline \multirow{2}{*}{2.} & Gender & Female & 77 & 53 \\
& & Male & 67 & 47 \\
\hline \multirow{3}{*}{3.} & \multirow{2}{*}{ Type of Family } & Nuclear & 88 & 61 \\
& & Jointly & 56 & 39 \\
\hline & & Private Sector & 77 & 54 \\
4. & Occupation & Government & 9 & 16 \\
& & Business & 35 & 6 \\
& & Other & & 24 \\
\hline \multirow{2}{*}{5.} & Educational & Non & 71 & 49 \\
& Stream & Engineering & 73 & 51 \\
\hline
\end{tabular}

TABLE 2 - Level of Internet Addiction

\begin{tabular}{|c|c|c|c|c|}
\hline S.No & Variables & Particulars & Frequency & Percent \\
\hline 1. & Internet Access & $\begin{array}{l}\text { Daily Usage } \\
\text { Weekly once }\end{array}$ & $\begin{array}{l}113 \\
31 \\
\end{array}$ & $\begin{array}{l}78 \\
22 \\
\end{array}$ \\
\hline 2. & $\begin{array}{l}\text { Knowledge of } \\
\text { Internet }\end{array}$ & $\begin{array}{l}\text { Yes } \\
\text { No }\end{array}$ & $\begin{array}{l}1400 \\
0\end{array}$ & $\begin{array}{l}100 \\
0\end{array}$ \\
\hline 3. & Mode of Usage & $\begin{array}{l}\text { Mobile } \\
\text { Laptop }\end{array}$ & $\begin{array}{l}33 \\
11 \\
\end{array}$ & $\begin{array}{l}92 \\
8 \\
\end{array}$ \\
\hline 4. & $\begin{array}{l}\text { Age of First } \\
\text { Internet Use }\end{array}$ & $\begin{array}{l}15 \text { and above } \\
10 \text { to } 15\end{array}$ & $\begin{array}{l}47 \\
97 \\
\end{array}$ & $\begin{array}{l}32 \\
68 \\
\end{array}$ \\
\hline 5. & $\begin{array}{l}\text { Internet Using } \\
\text { Time }\end{array}$ & $\begin{array}{l}3 \text { to } 5 \mathrm{Hrs} \\
1 \text { to } 3 \mathrm{Hrs}\end{array}$ & $\begin{array}{l}96 \\
48\end{array}$ & $\begin{array}{l}66 \\
34\end{array}$ \\
\hline 6. & $\begin{array}{l}\text { Availability of } \\
\text { Internet }\end{array}$ & $\begin{array}{l}\text { Residency } \\
\text { Hostel }\end{array}$ & $\begin{array}{l}63 \\
81\end{array}$ & $\begin{array}{l}44 \\
56\end{array}$ \\
\hline
\end{tabular}




\begin{tabular}{|c|l|l|l|l|}
\hline & & Does not & 0 & 0 \\
& & Apply & 14 & 10 \\
7. & \multirow{3}{*}{ Staying Online } & Rarely & 21 & 14 \\
& & Occasionally & 81 & 56 \\
& & Frequently & 9 & 6 \\
& & 19 & 14 \\
\hline
\end{tabular}

TABLE 3 - Implications of Internet Addiction

\begin{tabular}{|c|c|c|c|c|}
\hline S.No & Variables & Particulars & Frequency & Percent \\
\hline 1. & $\begin{array}{l}\text { Neglecting House } \\
\text { Hold Work }\end{array}$ & $\begin{array}{l}\text { Does not } \\
\text { Apply } \\
\text { Rarely } \\
\text { Occasionally } \\
\text { Frequently } \\
\text { Often } \\
\text { Always }\end{array}$ & $\begin{array}{l}0 \\
18 \\
13 \\
58 \\
31 \\
24\end{array}$ & $\begin{array}{l}0 \\
13 \\
9 \\
40 \\
21 \\
17\end{array}$ \\
\hline 2. & $\begin{array}{l}\text { Suffered } \\
\text { Academic } \\
\text { performance }\end{array}$ & $\begin{array}{l}\text { Does not } \\
\text { Apply } \\
\text { Rarely } \\
\text { Occasionally } \\
\text { Frequently } \\
\text { Often } \\
\text { Always }\end{array}$ & $\begin{array}{l}27 \\
18 \\
21 \\
26 \\
39 \\
13\end{array}$ & $\begin{array}{l}19 \\
13 \\
14 \\
18 \\
27 \\
9\end{array}$ \\
\hline 3. & $\begin{array}{l}\text { Gets Moody, } \\
\text { Depressed, Feeling } \\
\text { nervous when in } \\
\text { offline }\end{array}$ & $\begin{array}{l}\text { Does not } \\
\text { Apply } \\
\text { Rarely } \\
\text { Occasionally } \\
\text { Frequently } \\
\text { Often } \\
\text { Always }\end{array}$ & $\begin{array}{l}22 \\
16 \\
20 \\
43 \\
17 \\
26\end{array}$ & $\begin{array}{l}15 \\
11 \\
14 \\
30 \\
12 \\
18\end{array}$ \\
\hline 4. & $\begin{array}{l}\text { Getting Life with } \\
\text { Soothing Thoughts } \\
\text { of internet }\end{array}$ & $\begin{array}{l}\text { Does not } \\
\text { Apply } \\
\text { Rarely } \\
\text { Occasionally } \\
\text { Frequently } \\
\text { Often } \\
\text { Always }\end{array}$ & $\begin{array}{l}53 \\
17 \\
8 \\
27 \\
19 \\
20\end{array}$ & $\begin{array}{l}37 \\
12 \\
5 \\
19 \\
13 \\
14\end{array}$ \\
\hline 5. & $\begin{array}{l}\text { Expectation going } \\
\text { online again }\end{array}$ & $\begin{array}{l}\text { Does not } \\
\text { Apply } \\
\text { Rarely } \\
\text { Occasionally } \\
\text { Frequently } \\
\text { Often } \\
\text { Always }\end{array}$ & $\begin{array}{l}26 \\
24 \\
9 \\
41 \\
23 \\
21\end{array}$ & $\begin{array}{l}18 \\
17 \\
6 \\
28 \\
16 \\
15\end{array}$ \\
\hline 6. & $\begin{array}{l}\text { Making people } \\
\text { lonely }\end{array}$ & $\begin{array}{l}\text { Yes } \\
\text { No }\end{array}$ & $\begin{array}{l}93 \\
51\end{array}$ & $\begin{array}{l}65 \\
35\end{array}$ \\
\hline 7. & $\begin{array}{l}\text { Loosing Sleeping } \\
\text { Hours }\end{array}$ & $\begin{array}{l}\text { Yes } \\
\text { No }\end{array}$ & $\begin{array}{l}111 \\
33\end{array}$ & $\begin{array}{l}77 \\
23\end{array}$ \\
\hline 8. & $\begin{array}{l}\text { Lack of Face to } \\
\text { Face } \\
\text { Communication }\end{array}$ & $\begin{array}{l}\text { Yes } \\
\text { No }\end{array}$ & $\begin{array}{l}85 \\
59\end{array}$ & $\begin{array}{l}59 \\
41\end{array}$ \\
\hline 9. & Getting worries & $\begin{array}{l}\text { Yes } \\
\text { No }\end{array}$ & $\begin{array}{l}66 \\
78\end{array}$ & $\begin{array}{l}46 \\
54\end{array}$ \\
\hline 10. & $\begin{array}{l}\text { Losing their Time } \\
\text { and Money }\end{array}$ & $\begin{array}{l}\text { Yes } \\
\text { No }\end{array}$ & $\begin{array}{l}87 \\
57\end{array}$ & $\begin{array}{l}60 \\
40\end{array}$ \\
\hline 11. & $\begin{array}{l}\text { Facing physical } \\
\text { problem }\end{array}$ & $\begin{array}{l}\text { Yes } \\
\text { No }\end{array}$ & $\begin{array}{l}53 \\
91\end{array}$ & $\begin{array}{l}37 \\
63\end{array}$ \\
\hline 12. & $\begin{array}{l}\text { Facing } \\
\text { Psychological } \\
\text { Problem }\end{array}$ & $\begin{array}{l}\text { Yes } \\
\text { No }\end{array}$ & $\begin{array}{l}69 \\
75\end{array}$ & $\begin{array}{l}48 \\
52\end{array}$ \\
\hline
\end{tabular}

\begin{tabular}{|c|l|l|l|l|}
\hline 13. & $\begin{array}{l}\text { Facing family } \\
\text { problem }\end{array}$ & $\begin{array}{l}\text { Yes } \\
\text { No }\end{array}$ & $\begin{array}{l}42 \\
102\end{array}$ & $\begin{array}{l}29 \\
71\end{array}$ \\
\hline 14. & $\begin{array}{l}\text { Facing problem } \\
\text { with friends }\end{array}$ & $\begin{array}{l}\text { Yes } \\
\text { No }\end{array}$ & 53 & 37 \\
92 & 63 \\
\hline
\end{tabular}

\section{MAJOR FINDINGS OF THE STUDY}

1. An absolute (100\%) of the respondents belonging to 17 to 19 years old.

2. More than half of the respondents $(53 \%)$ gender is female

3. It is observed that 61per cent live in nuclear family

4. The more than half of the respondents $(54 \%)$ work for private sector

5. Half of the respondents (51\%) were from arts and science departments.

6. The majority of the respondents $(78 \%)$ are daily users of internet.

7. A vast majority of the respondents (92\%) access internet from their mobile phones.

8. The Most of the respondents (68\%) age of first using internet falls between 10 to 15 years .

9. Around $66 \%$ were using internet for 3 to 5 hours every day.

10. The majority of the respondents $(56 \%)$ access internet while they were in hostel.

11. More than half of the respondents (56\%) frequently stay online for longer period of time.

12. Less than half of the respondents $(40 \%)$ use to neglecting their work frequently as they engage in Internet activity.

13. More than one third of the respondents (27\%) often suffer in their academic activity due to excessive use of internet.

14. Nearly one third of the respondents (28\%) frequently anticipate going online again.

15. One third of the respondents (30\%) when offline become moody, depressed and nervous

16. It also shows that 59 per cent lose direct contacts with family members and friends.

17. The one third $(37 \%)$ of the respondents accepted that they are facing problem with their friends due to excess internet usage.

18. Around 60 per cent started feeling that they are losing their time and money.

19. Whereas 65 per cent of the respondents agrees that internet makes people lonely.

20. Majority $(77 \%)$ of the respondents lose their sleeping hours.

21. Majority ( $46 \%$ ) of the respondents stated having a feeling of worry when they were in offline.

22. Nearly 37 per cent of the respondents face physical problem due to excessive use of internet.

23. Nearly half ( $48 \%)$ of the respondents were facing psychological problem due to excessive use of internet.

24. One third $(29 \%)$ of the respondents were facing family problems due to excess of internet usage

\section{VI.CONCLUSION}

The study reveals about the excessive amount of time 
spent by the adolescent students. This have a serious implication of their sleeping hours, wasting of time, money, lack in learning hours and finally losing direct contact with their friends and family.

It can also be observed that the adolescent students were connected to many known and unknown friend as they use Internet. They access through emails and share study materials. The shared materials can also be referred with the previous studies. But the excessive use of the web brings Internet addiction as a major issue among the students leading to family and social problems.

Web conjointly brings a lot of disappointment among the students lay to rest human relationship and face to face interaction. It consequently ends up in many issues like insomnia, waste of your time, lack of power, abandonment of family, privacy treats, physically inactive, cyber bulling, cheating and ethical corruption. When Technology used productively brings progress and leads to scale up and elevate to level of advancements in incalculable specializations. The younger Adolescent ought to use the technology in appropriate manner and should be aware of balancing their invaluable life and use the technology advancement and research facilities for progressive functions with larger responsibility of national building.

\section{REFERENCES}

1. Andreassen, C. S., Billieux, J., Griffiths, M. D., Kuss, D. J., Demetrovics, Z., Mazzoni, E., \& Stale, P. (2016). The relationship between addictive use of social media and video games and symptoms of psychiatric disorders:

a large-scale cross-sectional study. Psychology of Addictive Behaviors, 30(2), 252-265. doi:10.1037/adb0000160 PMID:26999354

2. Yinghua ye \&linlin(2015)examining relations between locus of control, loneliness, subjective well-being, and preference for online social interaction. 116, 1, 164-175.

3. Öztürk, C., Bektas, M., Ayar, D., Özgüven Öztornac1, B., \& Yağc1, D. (2015). Association of Personality Traits and Risk of Internet Addiction in Adolescents. Asian Nursing Research, 9(2), 120-124. doi: 10.1016/ j.anr.2015.01.001

4. Chathoth, v., Kodavanji, B., Kumar, N., A., N, R., Kini, R., D., \&Pai, R., S.,(2014) Impact of internet use on lifestyle in undergraduate medical students

5. Kodvanji, B., Chathoth, V., Kumar, N.A., Kini, R.D., Pai, S.R. (2014).Impact of Internet use on lifestyle in undergraduate medical students. International Journal of Biomedical Research, 5 (3).

6. Leo Sang-Min \&Whang, Sujin Lee, Geunyoung Chang (2014) Internet Over-Users' Psychological Profiles:ABehaviorSampling Analysis on Internet Addiction. 6(2): 143-150.

7. Servidio, R. (2014). Exploring the effects of demographic factors, Internet usage and personality traits on Internet addiction in a sample of Italian university students. Computers in Human Behavior, 35, 85-92. doi:10.1016/j.chb.2014.02.024.

8. Azizah Zainudin et all (2013), Impacts due to internet addiction among malaysian university students, International Journal of Asian Social Science, 2013, 3(9):1922-1928

9. Young, K. S., Pistner, M., O’Mara, J., \& Buchanan, J. (1999). Cyber disorders: The mental health concern for the new millennium. Cyberpsychology \& Behavior, 2(5), 475-479. doi:10.1089/cpb.1999.2.475 PMID:19178220 